\title{
Students' Critical Thinking in Writing Background of Research
}

\author{
Sigit Pramonojati \\ English Language Education Department, \\ UIN Sunan Ampel Surabaya \\ Dova Navy Carella \\ English Language Education Department, \\ UIN Sunan Ampel Surabaya
}

\begin{abstract}
Critical thinking is the way to express your ideas in paper critically. The purpose of critical thinking is expressing your written because with critical thinking your written have high-scoring especially in academic writing. This study will investigate how critical thinking in students' introduction is and how the students' perceive. The researchers were collected with interview and analyze students' background of study. The participants of interview are 11 students of academic writing class and the author from background of research. The background of study that the researcher analysis is 5 background from the author that the researcher interviewed. The result of this study is critical thinking is one of important aspect that used for create background of study in research. Critical thinking is developing a writing that connects with an idea and fact by rationally, clearly and in depth to fixing the problem. Critical Thinking is the logical reason, clear explanation, the way to solve the problem, construct an argument, and explore and defend the ideas with evidence. Researchers' hope for the reader is the use of critical thinking in writing can make our writing be logic, well organized, rationally, and clearly. If the writer not using critical thinking surely be a mess, and not readable..
\end{abstract}

$\begin{array}{rrrr}\begin{array}{l}\text { Keywords: } \\ \text { background }\end{array} & \text { critical } & \text { thinking, } & \text { writing, } \\ \text { I. } & \text { INTRODUCTION } & \end{array}$

Critical thinking in academic writing is how you analyze or evaluate your ideas by your ways then you can express in a paper. Critical thinking is the key to succesfully expressing individuality in an academic writing. It is not enough for students to know that critical thinking is a key criterion of a high-scoring in academic writing, they should also know why and how critical thinking is useful to their general development as a student. Academic writing is one role important for the students to finish their study or assignment such as essay, thesis, article, and the

\author{
Wahyuni Dwi Fitriyah \\ English Language Education Department, \\ UIN Sunan Ampel Surabaya \\ Indah Yuli Kartika Sari \\ English Language Education Department, \\ UIN Sunan Ampel Surabaya
}

others form of assigments. To finish their assigment they have to think critically in their paper. The functional of critical thinking is defined by students creativity in expressing ideas or arguments that they have in a language that is easy to read and understand by others (Michelle Vyncke, 2012). However, before we write our argument with thinking crtitically, we have to sort an information and ideas to ensure your pick and only the most appropriate words or sentence that deliver your ideas on the readers for our writing.

Writing is claimed to be a higher form of critical thinking as well as a problem solving activity where a combination of various skills are knocked. Clearly writing proficiently necessitates build up a thinking and reasoning skills. Writing in a foreign language has proved to be a complex skill which needs special attention in EFL teaching and learning because complexity of the writing process, it is difficult to visualize a model for writing in term of its 'subskill' (Abbott \& Berninger, 1993; Grabe \&Kaplan, 1996). In writing academics can integrated students' critical thinking. Critical Thinking have a function that to help individual to attention the way one thinks in relationship to aspesific question, idea, or issue. Too many ways that we think through things like logical and generative. At the same time, one is always accesible is called cognitive bias. There are cognitive skills in critical thinking such as selfdirected, self-disciplined, self-monitored, and selfcorrective thinking (Paul \& Elder, 2005, p.1). Writing and critical thinking are seen as closely linked, and ability in writing is seen as an indication that students have mastered the cognitive skills required for university work (Weigle, 2002, p. 5). Freely and Steinberg (2000) said that the significance of discussions, debates and problem solving activities can foster students' critical thinking.Based on Bednarz (2004) that there are major of Critical Thinking such as Perception (individuals receive, interpret, and translate experiences), Assumptions (central to critical thinking), Emotions (creating and putting into place thinking and operating obstacle), Language 
(individuals think and problem solve through metaphors), Argument (claim), Fallacy (incorrect patterns of reasoning), Logic (deductive (based o fact) and inductive (based on hypotheses)), and Problem Solving (throughlogic).

The introduction of research should provide a background of research. The background of research is one of important part in a research. In the background of research, it is include an explanation of the area of the research to set context for the problem. An introduction generally consists of three components. The first part provides background information, the second part justifies the need to explore the area that is not known while the third component states the hypothesis or describes the purpose and objectives of the study (Jha KN, 2014). The background of research of a paper is critically important. Even if your results are quite good, unless you introduce your work well, interesting results can come across as boring or meaningless. Writing a good background of research typically means "straightforward" writing and generally lays out a kind of road-map for the paper to come. According to Reyes, there are three overarching goals of a good introduction: 1) ensure that you summarize prior studies about the topic in a manner that lays a foundation for understanding the research problem; 2) explain how your study specifically addresses gaps in the literature, insufficient consideration of the topic, or other deficiency in the literature; and, 3) note the broader theoretical, empirical, and/or policy contributions and implications of your research.

List of previous study about critical thinking in writing introduction by finding from NurayAlagozlu (2007), the result of her study is critical thinking is not emphasized in the Turkish educational system. Since language learning is regarded as part of a memorization-based system of education in Turkey and learners are not independent enough (Palfreyman, 2003; Tekışık, 2005, pp. 12-13; Sert, 2006), EFL students fail in expressing their own ideas with their own words and thinking critically in content-based courses. Another previous study that conducted by MansoorFahim and PanteaHashtroodi (2012) showed that techniques of critical thinking can help the students to become critical thinkers because the improvement was positive, yet it cannot help them to write more argumentative essays, for the fact that the improvement was not significant. The article from Kabilan (2002) called Creative and Critical Thinking in Language Classrooms notes that only using the language and knowing the meaning is not enough, in order to become proficient in a language, learners need to use creative and critical thinking through the target language.
Considering the importance of critical thinking in writing introduction, therefore this present studies tries to seek critical thinking in depth. This study will investigate how critical thinking in students' introduction is and how the students' perceive. The researchers were collected with interview and analyze students' introduction. This research will also be guided by the theories that have been stated by the findings of the previous studies.

\section{METHOD}

This study will involve the students Academic Article Writing of English Teacher Education Department year 2019 at State IslamicUniversity of Sunan Ampel Surabaya. The are four Academic Article Writing class and every class in Academic Article Writing have a group research, in every group research consist three until four students. The participation in this study was selected.The researcher choose 5 group of research as a participants and every group consist 3 students. The total participants of this study is 15 students, and consist of 13 females and 2 male students' Academic Article Writing class. The participants will interviewed then their background will analyze by the researcher.

There are two ways to collect data those are content analsis and interview. Data collection technique is the way the researcher collects the data empirically and objectively (Devi Rahayu, 2015). Data collection technique is the most important step in the research, because the main purpose of the research is to get the data (Prof. Dr. Sugiono, 2015).For collecting the data, the researcher uses content analysis an interview as the instrument. There are several procedures performed by researchers during the study. The procedures for content analysis are first researcher looking for a background of research from Academic Article Writing class, second background will selected, third researcher will read analyze the background of research was selected using table score critical thinking from Finken and Ennis's book (table 01), and the last researcher will coding the data and make a conclusion. Procedures for interviewed are first researcher making the questions for interviewed, The interviewed were open minded questions. There are five questions and they could answer related their experience writing background of research use critical thinking. The first question is students' understanding in critical thinking, second is the criteria critical thinking should be put in writing background of research, third is the difficulties writing background of research using critical thinking, fourth is the factors critical thinking in writing background of research, and the last is strategies to use critical thinking in writing background of research. Interview purposed to know and understand what's critical thinking with 
There are 6 aspects that can analyses critical their own opinion or idea, second researcher will ask the questions to the participants who background was analyzed, after getting the data researcher coding the data and explains it decriptively with making conclusion as the result of the research.

If already getting the data which has been collected, the background of research was sellected and answered by the participant, for the next step rearcher will analyze the data. Data analysis is process of gathering, modeling, and transforming data with the useful information, suggesting conclusions, supporting decision making (Maeleong, Lexy J, 2001). In this study, data were collected using content analysis and interviewed. First to analyze data content analysis were selected researcher use table score critical thinking from Finken and Ennis's book to measure their critical thinking. Researcher will read and analyze the background of research were selected then researcher will give the score based on paticipants' critical thinking in writing background to give the score researcher give the point from table score critical thinking byFinken and Ennis's book. There are six aspects there are focus, supporting reasons, reasoning, organization, conventions, and integration and every aspect have six score (table 01 ). If the data has been scored researcher will coding the data where is the background of research have a good critical thinking in writing background of research, then researcher will making a conclusion. After analyze the background of research continue with analyze the interviewed participant. Data for the interview will get from participants that created the background of study. If the data interviewed has been collected researcher will read the data then after read the data researcher will coding the data. To coding the data the researcher started to analyze the data. This is also to identify which information that needs to be used in this study or need to be reduced. For example, when the researcher did the interview and transcribed into text. After coding the data will continue with Conclude the data. The last step of analyzing data is to conclude the whole research after analyzing data is done and presented from the description

\section{FINDINGS AND DISCUSSION}

\section{Content analysis}

According Finken and Ennys (1993), there are 3 features of the guide critical thinking. The first is text-level. This feature consists of focus, supporting reason, reason, and organization. The second is sentence-level. This feature just consists of conventions. The last is holistic. This feature just consists of integration. thinking in background of study. The first aspect is focus. From 5 backgrounds, there are 2 background is perfect and get 6 points. 6 points means that all main points of background are specified and maintained. While, there are 3 background from 5 background is average and get 4 points. 4 points mean that the background have bare bones, position clear, and main point previewed. The second aspect is supporting reason. There are 3 of 5 background is good and get 5. 5 points mean that in the background of study have most source credible, most reason / evidence believable, often at second level, specific (where appropriate), and clear. While from 2 other background, 1 background get 4 points in aspect supporting reason. 4 points mean that the background of study have some sources credible, the reason / the evidence generally believable, sometimes second level, specific (where appropriate), and clear. The other background gets 3 points in aspect supporting reason. 3 points mean that the background of study have some sources and/or reasons/evidence dubious, and some vagueness. The next aspect is reasoning. There are 2 of 5 background is good and get 5 points. 5 points

\begin{tabular}{|l|c|c|c|c|c|}
\hline & $\begin{array}{c}\text { Back } \\
\text { grou } \\
\text { nd A }\end{array}$ & $\begin{array}{c}\text { Back } \\
\text { grou } \\
\text { nd B }\end{array}$ & $\begin{array}{c}\text { Back } \\
\text { grou } \\
\text { nd C }\end{array}$ & $\begin{array}{c}\text { Back } \\
\text { grou } \\
\text { nd D }\end{array}$ & $\begin{array}{c}\text { Back } \\
\text { grou } \\
\text { nd E }\end{array}$ \\
\hline Focus & 4 & 4 & 4 & 6 & 6 \\
\hline $\begin{array}{l}\text { Supporti } \\
\text { ng } \\
\text { reason }\end{array}$ & 4 & 5 & 3 & 5 & 5 \\
\hline $\begin{array}{l}\text { Reasoni } \\
\text { ng }\end{array}$ & 4 & 4 & 4 & 5 & 5 \\
\hline $\begin{array}{l}\text { Organiz } \\
\text { ation }\end{array}$ & 4 & 4 & 4 & 6 & 6 \\
\hline $\begin{array}{l}\text { Conventi } \\
\text { ons }\end{array}$ & 5 & 5 & 5 & 5 & 6 \\
\hline $\begin{array}{l}\text { Integrati } \\
\text { on }\end{array}$ & 5 & 5 & 5 & 5 & 6 \\
\hline
\end{tabular}

mean that the background of study have conclusion well supported, alternatives well recognized, and clear. While, 2 background is average and get 4 points. 4 points mean that the background have moderate support, alternatives mentioned fairly, and some vagueness. The fourth aspect is organization. There are 2 of 5 background is perfect and get 6 points. 6 points mean that in the background of study, there is strong support, alternatives thoroughly addressed, and clear. While, 3 background are good enough and get 4 points. 4 
points mean that in the background of study have some cohesion and coherence from relating to topic and plan is clear. The fifth aspect is conventions. 1 background is perfect and get 6 points. 6 points mean that in the background of study, there is no major errors and one or two minor errors. While, 4 of 5 backgrounds are good and get 5.5 points mean that in the background of study have a few minor errors but no more than one major error. The last aspect is integration. 1 background is perfect and get 6 point. 6 points mean that the background of study supported all features evident and equally well developed. While, 4 of 5 backgrounds are good and get 5 points. 5 points mean that the background of study supported features present, but not equal.

\section{Interview}

The valid data interviewed from 15 respondent is 11. The first questions the most respondents' ague that definition of critical Thinking is the way to develop a writing that connects it with an idea and fact by rationally and in depth to fixing the problem. Based on Paul, Fisher, and Nosich stated that Critical Thinking is a Thinking's mode that consist of content or problem that improve the quality people thinking with proficient of the structures implicit in thinking. The other respondents have different answers; They said Critical thinking is the way to think clearly in writing to produce good writing. Second question respondents said the same answer that to write background of research the researchers must understand about their research. In addition, if the researcher understand with their research they will be easy to think out the logical reason, clear explanation, the way to solve the problem, construct an argument, and explore and defend the ideas with evidence. Third question about the difficulties in writing background using critical thinking. When they are developing the ideas to produce a logical way, well and smoothly, good transition, and good arrangement. While, there are 5 respondents said that it is difficult in adjusting the theories from experts to be good organized with their research. The next question is about factors critical thinking in writing background, people who are using the critical thinking in writing, they can make writing a good organization, smoothly background, and connect and attract. While, there are 2 respondents said that using critical thinking we can find the way to analyze, interpret, and explain every sentence in the background. Based on Butterworth and Thwaites (2013) stated that Thinking is a skill that related to higher-order activities such as Evaluating, Analyzing and explaining that will connected with the challenges such as problem solving and evaluating complex arguments. The last question is the strategies use critical thinking in writing background, the all respondents argues that strategies use critical thinking in writing background is read many background, journals and books to support their prior knowledge. While, there are 2 respondents said another that the strategies use critical thinking in writing background is correction their background is correct or not that connect with their purpose and the topic.

\section{CONCLUSION}

From the result of content analysis, the researcher can conclude that critical thinking is one of aspect that using for create background of study. The critical thinking can analyses with rubric in Finken and Ennys's book. On the background of study that has been analyzed, there are 2 background that almost have perfect score. The perfect score can be obtained and includes 6 aspect from rubric in Finken and Ennys's book. The authors use their critical thinking when create it include 6 aspects, such as focus, supporting reason, reasoning, organization, conventions, and integrations. Background of study called good and critically if there are 6 aspect in the background. The limitation of the study, the topic of this study is selected randomly, students who had taken from certain academic article writing class of English Teacher Education Department at State Islamic University of Sunan Ampel Surabaya taught by lecturers Miss Bella. In this study, the researchers chooses some group had selected which write a background of research in their class students. The researchers only analyse the background of research, and for the interviewed session also from the group were selected by researcher. Based on the conclusions above, the researchers would like to present recommendation, the recommendation for the researchers who write a background of research are they should be have some strategies to make easier write a background using critical thinking. In addition they can read a lot some resources such as book, article, or journal to make their idea rational, good, or connect with their research.

The result of the interview shows that the respondents understand about what is critical thinking. Based on their answer the researchers conclude that critical thinking is the way to develop a writing that connects with an idea and fact by rationally, clearly and in depth to fixing the problem. The criteria critical thinking in writing based on their answer, the researchers conclude that the criteria critical thinking in their writing is the writer must understand about the own research so it will be easy to think outthe logical reason, clear explanation, the way to solve the problem, construct an argument, and explore and defend the ideas with evidence. The difficulties based on the respondents' answer is when they are developing the ideas to produce a logical way, well and 
smoothly, good transition, and good arrangement and adjusting the theories from experts to be good organized with their research. The factors of critical thinking in writing background based on their answer concluded by the researchers that when we using critical thinking in writing of background it will be good organization, smoothly background, and connect and attract and find the way to analyze, interpret, and explain every sentence in the background. The strategies using critical thinking in writing a background is we must read many background, journals and books to support our prior knowledge.

\section{REFERENCES}

[1] Butterworth, John. \& Thwaites, G, 2013. Thinking Skills: Critical Thinking and Problem Solving (ed 2). Italy: L.E.G.O. S.p.A

[2] Devi Rahayu, Undergraduate Thesis: "The Implementation of Students Peer Assignment in Writing Descriptive Text at Tenth Grade of Trisila Senior High School of Surabaya" (Surabaya: State Islamic of University of Sunan Ampel Surabaya, 2015)

[3] Finken and Robert H. Ennis, Illinois critical thinking essay test, Champaign, 1993

[4] Maeleong, Lexy J, Metode Penelitian Kualitatif (Bandung: PT. Remaja Rosdakarya, 2001), 82.

[5] Prof. Dr. Sugiono, Metode Penelitian Pendidikan Pendekatan Kuantitatif, Kualitatif, dan R\&D(Bandung: Alfabeta, 2015),

[6] https://www.google.com/amp/s/www.legit.ng/amp/117494 1-how-write-background-study-research.html

[7] https://www.slideshare.net/mobile/guest349908/theresearch-proposal

[8] https://www.google.com/amp/s/majorium.wordpress.com/ 2013/11/26/seven-components-of-critical-thinking-2/amp/ 